\title{
High Blood Pressure and Its Correlates among Assistant Physical Education Teachers in Republic of Benin (West Africa)
}

\author{
Polycarpe Gouthon ${ }^{1}$, Barnabé Akplogan ${ }^{2}$, Jean-Marie Falola ${ }^{2}$, Houndjovi Pierre Dansou ${ }^{3}$, \\ Hippolyte Agboton ${ }^{4}$, Solange Adégnika ${ }^{1}$, Issiako Bio Nigan ${ }^{1}$ \\ ${ }^{1}$ Laboratory of PSA and Motricity, National Institute of Youth, Physical Education and Sport (INJEPS), \\ University of Abomey-Calavi (Benin), Porto-Novo, Republic of Benin \\ ${ }^{2}$ Laboratory of Biomechanics and Performance (LABIOP), National Institute of Youth, Physical Education and \\ Sport (INJEPS), University of Abomey-Calavi (Benin), Porto-Novo, Republic of Benin \\ ${ }^{3}$ Laboratory of Exercise Physiology, National Institute of Youth, Physical Education and Sport (INJEPS), \\ University of Abomey-Calavi (Benin), Porto-Novo, Republic of Benin \\ ${ }^{4}$ Cardiology Department of the National Universitary Hospital of Cotonou (Benin), Unity of Formation and Research in \\ Cardiology, Faculty of Health Science, University of Abomey-Calavi (Benin), Porto-Novo, Republic of Benin \\ Email: goupoly@yahoo.fr
}

Received January $30^{\text {th }}, 2012$; revised February $28^{\text {th }}, 2012$; accepted April $30^{\text {th }}, 2012$

\begin{abstract}
Objective: This cross-sectional study carried out in Republic of Benin, aimed at assessing the relation between high blood pressure (HBP) and its correlates in an exhaustive sample of 123 Assistant physical education teachers (APE teachers), enrolled in a two-year in-service training. Methods: These teachers have been interviewed and clinically tested. The lifestyle, blood pressure, three indexes of adiposity, blood lipids, white blood cells and neutrophils counts and plasma C-reactive protein were the main study variables. Results: HBP was present in $34.1 \%$ of the teachers. The three main factors associated to HBP, that had the higher rates were neck circumference (78.3\%), the biological index of atherogenicity (72.2\%), and waist circumference $(44.2 \%)$. Neck circumference was the most relevant modifiable variable to explaining HBP in this group ( $\mathrm{OR}=3.14 ; 95 \%$ IC: 1.09 - 9.00; $p=0.033)$. Conclusions: The teachers studied must keep on exercising as early as their primary training comes to an end. Doing so, they could avoid overweight and reduce the risk of hypertension.
\end{abstract}

Keywords: High Blood Pressure; Physical Education Teacher; Cardiovascular Disease; Inactivity

\section{Introduction}

Blood pressure is determined by the interaction of hemodynamic factors as cardiac output, total peripheral resistance (Daniels et al., 1996) and non-hemodynamic ones as age, sex, blood lipids, heredity, etc. The association of these factors induces the high inter-individual variability of blood pressure values recorded in a given population. These pressure values can increase abnormally in a subject, even in a group, so that a light and temporary high blood pressure (HBP) may appear, that is a systolic pressure $\geq 140 \mathrm{~mm} \mathrm{Hg}$ and/or a diastolic pressure $\geq 90$ $\mathrm{mm} \mathrm{Hg}$ (WHO, 1999) and become more often a sustained and severe disease.

The importance of HBP (or hypertensive) pathology within the cardiovascular diseases in Africa is well established (Agboton et al., 1987). Indeed, arterial hypertension in black peoples has become during last decades an important problem of public health, because of its increasing gravity which involves high prevalence, morbidity and mortality (Aubry, 2003). According to Fourcade et al. (2007), there were 80 million patients with arterial hypertension in sub-Saharan Africa in 2000 and they will probably be 150 millions in 2025 . In Africa, the noncontrolled arterial hypertension ( $>80 \%$ of the cases), associated with ageing, obesity, a hyper-salted food weak in potassium and other atherogenous factors, seems to be the main risk factor for hemorrhagic-caused cerebrovascular events (Aubry, 2003;
Guenette \& Mantha, 2005).

In the therapeutic "arsenal" used against this disease, regular practice of aerobic exercise (brisk walk, race, cycling, dance, swimming, etc.) requesting large muscular groups and other lifestyle rules are often primarily suggested (WHO, 1999). They help in achieving high physical fitness (Ortlepp et al., 2003), reducing systolic pressure to an average of 4 to $9 \mathrm{~mm}$ $\mathrm{Hg}$, even if there is no weight loss (Guenette \& Mantha, 2005). Though this practice prevents blood pressure increase, many PE teachers in Republic of Benin cease any physical activity or reduce significantly its frequency, a few years after the end of their initial training. It is well known that stopping physical activities or exercise training (for long or short duration), referred to as detraining, causes a regression of the physiological adaptations acquired while training (Mujika \& Padilla, 2001; Mujika \& Padilla, 2000; Nelson et al., 1986). The literature data also state that detraining induces in high level athletes, an increase in the arterial hypertension risk factors such as overweight, increased resting heart rate, dyslipidemia, hyperglycemia (Petibois et al., 2004; Petibois \& Deleris, 2003; Oshida et al., 1991). The phenomenon is the same for the blood pressure itself which increases gradually, even in teenagers (Hagberg et al., 1983).

In this context, only a periodic assessment of the hypertensive risk and the associate risk factors, when an approach based on an absolute cardiovascular risk (Gaziano et al., 2005) may 
not be used, can help to define the proportion and profile of PE teachers with HBP in republic of Benin. In case the correlate factors to HBP may be modifiable ones, counsels addressing lifestyle changes can be given to the involved teachers.

Such assessment strategies have been implemented in countries like Sweden, Estonia and Croatia in Europe (MisigojDurakovic et al., 2004; Pihl et al., 2002; Sandmark, 2000), even the Congo in Africa (Mbemba et al., 2007). They may nevertheless be undertaken in other African populations who may be (or not be) genetically or environmentally different each from other (Opie \& Yackoob, 2005). This study which contributes to achieving this issue was undertaken to analyze HBP and its correlates among a population of APE teachers in Republic of Benin.

\section{Materials and Methods}

\section{Nature of the Study and Settings}

It is a cross-sectional study, carried out in September 2008 at the National Institute of Youth, Physical Education and Sport of Porto-Novo (INJEPS), of the Republic of Benin (West Africa).

\section{Study Population and Sampling}

The population studied is the Assistant PE teachers APE, surveyed during the first year of a two year in-service training. A non- probability and exhaustive sample was constituted of all the teachers satisfying the following inclusion criteria: to be a male APE teacher exerting in Republic of Benin and regularly Regis- tered on the official list of the trainees of INJEPS; to be volun- tary, to have a healthy look or be without any recognised dis- ease like arterial hypertension. The untreated sick teachers, those having personal antecedents of cardiovascular events or untreated diabetes Mellitus, were not integrated into the study sample.

During a meeting with the INJEPS' Academic Direction and the APE teachers, the information related to the study were presented, in order to get the Institutional approval and the informed consent of the teachers to take part in the study, with respect to the convention of Helsinki (1964). Afterwards, 129 teachers out of $144(89.5 \%)$ volunteered to participate in the study, but six among them were not available for some measures undertaken in 123 subjects.

\section{Study Design}

Anthropometric variables are measured three times successively, and the average recorded, by trained PE teachers. Height is measured with a vertical height gauge (sensitivity of $0.5 \mathrm{~cm}$ ), weight with a scale (Seca, Germany; sensitivity of $0.5 \mathrm{~kg}$ ) and circumferences with a non-extensible tape measure (Butterfly). Neck circumference is measured (within $1 \mathrm{~mm}$ ) just under the top of Adam's apple (Ben Noun \& Laor, 2003) and waist circumference within $1 \mathrm{~mm}$ too, according to the recommendations of Mac Dougall et al. (1988).

Heart rate monitors (Accurex Plus, Polar, Finland) are used to measure the resting heart rate and a manual sphygmomanometer is used to measure systolic and diastolic blood pressure, referring to the Korotkoff I and Korotkoff V sounds. Cardiovascular variables are also measured by trained nurses three times over a period of $30 \mathrm{~min}$, in the left arm of the subjects when they are seated and the average values are recorded.
Blood lipids are assayed by the enzymatic and colorimetric method, using a UNISPEC 22D spectrophotometer. C-reactive protein (CRP) is assayed by semi-quantitative method, with the CRP Latex ${ }^{\circledR}$ kit (Reactivos LPG, Spain), by successive dilutions from $1 / 2$ to $1 / 16$. White blood cell (WBC) and neutrophil (NEU) counts are assessed on the whole blood, using an automat Medonic CA620/530 (Boule Medical, Sweden). Blood samples $(10 \mathrm{~mL})$ are drawn by venipuncture into EDTA tubes, early in the morning (before $8 \mathrm{am}$ ), at the antecubital fold of the left elbow, after a 12-hour fasting and a 24 hour-resting, e.g. without intense physical activity.

The other personal data are collected on individual questionnaire forms completed by each PE teacher.

\section{Study Variables}

Two groups of variables are selected: in one hand, high blood pressure (HBP) considered as the dependent variable, and in the other hand, anthropometric, biological and sociodemographic parameters, considered as correlates or independent variables.

\section{The Dependent Variable}

In this study, it is high blood pressure (HBP) defined as an occasional systolic and/or diastolic blood pressure $\geq 140 / 90$ $\mathrm{mm} \mathrm{Hg}$ (WHO, 1999). A subject with a systolic pressure (SBP) $<140 \mathrm{~mm} \mathrm{Hg}$ and a diastolic pressure (DBP) $<90 \mathrm{~mm} \mathrm{Hg}$ is considered to have a normal blood pressure (NBP).

\section{The HBP Correlates or Independent Variables}

Adiposity indexes

They are body mass index (BMI), neck and waist circumferences (NC and WC). BMI is calculated according to the formula BMI $\left(\mathrm{kg} / \mathrm{m}^{2}\right)=$ Weight $/$ Height $^{2}$, with weight measured in $\mathrm{kg}$ and height in meter. Values of BMI $>30 \mathrm{~kg} \cdot \mathrm{m}^{2}, \mathrm{NC}>37 \mathrm{~cm}$ (Ben-Noun \& Laor, 2003) and WC $>94 \mathrm{~cm}$ (Pouliot et al., 1994), are considered as abnormal.

Blood lipids

The following blood lipids, total cholesterol (TC), HDLcholesterol (HDL-C), LDL-cholesterol (LDL-C), are assessed. Although triglycerides (TG) are considered as a metabolic syndrome marker, they are also assessed, since TG/low HDL-C has been found to be correlated to ischemic heart disease (Jeppesen et al. 2003). The biological index of atherogenicity (BIA) is calculated, according to the formula reported by Akplogan et al. (1985) in which BIA $=$ TC - HDL-C/HDL-C.

Values of TC $>2 \mathrm{~g} / \mathrm{L}, \mathrm{LDL}-\mathrm{C}>1.6 \mathrm{~g} / \mathrm{L}$, HDL-C $<0.40 \mathrm{~g} / \mathrm{L}$, TG $>2$ g/L (Boreham et al., 1993), BIA > 2 (Akplogan et al., 1985) are also recorded as abnormal.

Emerging risk markers of cardiovascular disease

Other variables considered as emerging risk markers of cardiovascular disease which are blood C-reactive protein (CRP), white blood cell count (WBC) and neutrophil count (NEU) are also measured. Abnormal values are CRP $>6 \mathrm{mg} / \mathrm{L}$, WBC $>$ $8000 \times 10^{9}$ cells $/ \mathrm{L}, \mathrm{NEU}>5000 \times 10^{9}$ cells $/ \mathrm{L}$ (Orakzai et al., 2006; Horne et al., 2005).

Sociodemographic and lifestyle variables

The following categorical variables with their respective modalities are surveyed through questionnaire addressed to each participant: age ( $\geq 50$ years or $<50$ years); seniority in the teaching profession ( $\geq 10$ years or $<10$ years); alcohol drinking (often, sometimes, never) and current tobacco consumption (yes or no). Given the difficulty of assessing objectively salt consump- 
tion in the conditions of this study, a subjective way is used to know if each teacher is conscious of salt overconsumption or not, by their response (yes or no) to the question. Personal experience of disease apart from hypertension was informed on by answering "yes" or "no" to the question. As none of the surveyed teachers affirmed they had leisure and competitive physical activity, daily average walking time (occupational and other opportunities) and movement on bicycle $(\geq 30 \mathrm{~min}$ or $<30$ $\min )$ are evaluated as indicators of physical activity.

\section{Data Analysis}

The data collected are processed with Statistica (Stat Soft Inc., version 5.5) and SPSS (version 11.5) softwares. Quantitative data are presented as mean value $(\mathrm{m}) \pm$ standard deviation. We transformed the quantitative variables used as HBP correlates into qualitative ones. The frequencies of HBP and each of its correlate in the study sample are then calculated and we undertake a bivariate analysis $\left(\mathrm{X}^{2}\right.$ test) between them. NC alone then associated with age and the three correlates which are signifycant at $p<0.10$ for the $\mathrm{X}^{2}$ test are used to achieve a step by step logistic regression. The level of significance of all statistical tests is set at $p<0.05$.

\section{Results}

\section{Demographics and Lifestyle of the Subjects}

As descriptive statistics of Table 1 shows the studied APE teachers are on average $48.2 \pm 4.61$ years old, with a seniority of $20.61 \pm 4.62$ years in the profession and a mean BMI of 25.7 $\pm 3.71 \mathrm{~kg} / \mathrm{m}^{2}$.

In the study sample, 128 teachers $(99.20 \%)$ usually move on motorcycle or in car and 22 among them (17.1\%) use to walk less than 30 minutes per day, including movements during the physical education (PE) courses. In this group, 63 teachers (48.8\%) affirmed to have personal antecedents of diseases (arterial hypertension not included), like malaria, joint pains, respiratory tract diseases, etc.

Table 1.

Mean values $\pm \mathrm{SD}$ of blood pressure, demographics and HBP correlates among assistant PE teachers APE in Republic of Benin.

\begin{tabular}{lcc}
\hline Variables & N & M \pm SD \\
\hline Demographics & 123 & $48.25 \pm 4.61$ \\
Age (years) & 123 & $20.61 \pm 4.62$ \\
Seniority in the profession (years) & 123 & $173.30 \pm 6.92$ \\
Height $(\mathrm{cm})$ & 123 & $77.63 \pm 13.81$ \\
Weight $(\mathrm{kg})$ & & \\
Blood pressure & 123 & $133.51 \pm 18.92$ \\
Systolic blood pressure $(\mathrm{mm} \mathrm{Hg})$ & 123 & $79.75 \pm 12.19$ \\
Diastolic blood pressure $(\mathrm{mm} \mathrm{Hg})$ & & \\
HBP correlates & 123 & $25.73 \pm 3.71$ \\
Body mass index $\left(\mathrm{kg} / \mathrm{m}^{2}\right)$ & 123 & $91.79 \pm 10.70$ \\
Waist circumference $(\mathrm{cm})$ & 123 & $38.23 \pm 2.46$ \\
Neck circumference $(\mathrm{cm})$ & 123 & $69.88 \pm 6.36$ \\
Resting heart rate $(\mathrm{bpm})$ & 115 & $2.02 \pm 0.35$ \\
Total cholesterol $(\mathrm{g} / \mathrm{L})$ & 115 & $0.48 \pm 0.19$ \\
HDL-cholesterol $(\mathrm{g} / \mathrm{L})$ & 115 & $1.36 \pm 0.36$ \\
LDL-cholesterol $(\mathrm{g} / \mathrm{L})$ & 115 & $0.84 \pm 0.41$ \\
Triglycerides $(\mathrm{g} / \mathrm{L})$ & 115 & $4.53 \pm 1.69$ \\
White blood cell count $\left(10^{9} \times\right.$ cells/L) & 115 & $2.39 \pm 1.18$ \\
Neutrophil cell count $\left(10^{9} \times\right.$ cells/L) & \\
\hline
\end{tabular}

Note: M: mean value; SD: standard deviation; N: sample size; HBP: high blood pressure; PE: physical education.

\section{Frequencies of HBP and Its Correlates}

HBP is present in 43 teachers among 123, i.e. $35 \%$ of them (Figure 1), with the distribution presented in Table 2. The five correlates of HBP which have the highest frequencies of abnormal values in this group are: $\mathrm{NC}(78.3 \%)$, BIA $(72.9 \%)$, WC (44.2\%), LDL-C (22.5\%), and BMI (14\%). The percentages of the subjects who show high values of WBC, NEU, and CRP are low (respectively $3.9 \%, 3.9 \%$ and $4.7 \%$ ), but that of TG is null.

\section{Results of the $\mathrm{X}^{2}$ Test}

The results of the univariate analysis $\left(\mathrm{X}^{2}\right.$ test) are presented in Tables 3(a) and (b). The way they were evaluated showed that the variables related to lifestyle (tobacco, alcohol, salt, daily time of walk), blood lipids and the emergent risk factors do not significantly correlate to HBP in the studied group $(p>0.05)$. However, the percentage of subjects with $\mathrm{HBP}$ having a $\mathrm{NC} \geq 37 \mathrm{~cm}$

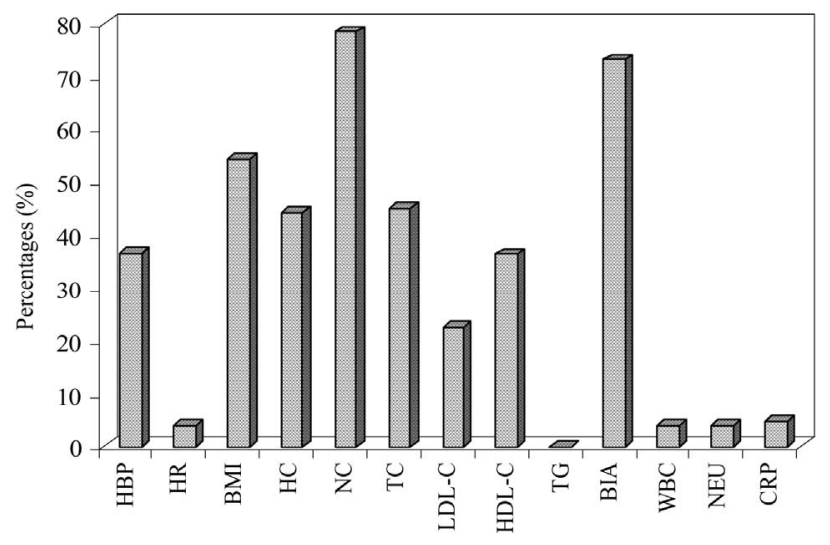

HBP and abnormal values of its correlate

Note: HR: heart rate; AHT: arterial hypertension; BMI: body mass index; WC: waist circumference; NC: neck circumference; TC: total cholesterol; LDL-C: LDL-cholesterol; HDL-C: HDL-cholesterol; TG: triglycerides; BIA: biologic index of atherogenicity; WBC: white blood cell count; NEU: neutrophil cell count; CRP: C-reactive protein.

Figure 1.

Frequencies of HBP and that of its correlates' abnormal values among assistant PE teachers in Republic of Benin.

Table 2.

Stratification of blood pressure values among Assistant PE teachers in Republic of Benin $(\mathrm{N}=123)$.

\begin{tabular}{ccc}
\hline \multicolumn{2}{c}{ Blood pressure values } & $\begin{array}{c}\text { Frequencies } \\
\text { (\%) }\end{array}$ \\
\cline { 1 - 2 } Systolic blood pressure & $81(65.8)$ \\
High blood pressure (HBP) & $\geq 140 \mathrm{~mm} \mathrm{Hg}$ & $42(34.1)$ \\
Stratification of HBP & $<160 \mathrm{~mm} \mathrm{Hg}-\geq 140 \mathrm{~mm} \mathrm{Hg}$ & $29(23)$ \\
Diastolic blood pressure & 9 mm Hg - $\geq 160 \mathrm{~mm} \mathrm{Hg}$ & $9(7.3)$ \\
Normal blood pressure (NBP) & $<90 \mathrm{~mm} \mathrm{Hg}$ & $4(3.2)$ \\
High blood pressure (HBP) & $\geq 90 \mathrm{~mm} \mathrm{Hg}$ & $94(76.4)$ \\
& $<100 \mathrm{~mm} \mathrm{Hg}-\geq 90 \mathrm{~mm} \mathrm{Hg}$ & $18(14.6)$ \\
Stratification of HBP & $<110 \mathrm{~mm} \mathrm{Hg}-\geq 100 \mathrm{~mm} \mathrm{Hg}$ & $7(5.7)$ \\
& $\geq 110 \mathrm{~mm} \mathrm{Hg}$ & $4(3.3)$ \\
\hline
\end{tabular}


Table 3(a).

Results of the $\mathrm{X}^{2}$ test between HBP and its correlates among Assistant $\mathrm{PE}$ teachers in Republic of Benin $(\mathrm{N}=123)$.

\begin{tabular}{|c|c|c|c|}
\hline Correlates of HBP & $\begin{array}{l}\text { Subjects with NBP } \\
\text { Frequencies (\%) }\end{array}$ & $\begin{array}{l}\text { Subjects with HBP } \\
\text { Frequencies }(\%)\end{array}$ & $p$ \\
\hline $\begin{array}{l}\text { Age (years) } \\
\geq 50 \\
<50\end{array}$ & $\begin{array}{l}33(57.8) \\
45(68.2)\end{array}$ & $\begin{array}{l}24(42.2) \\
21(31.8)\end{array}$ & 0.16 \\
\hline $\begin{array}{l}\text { Salt overconsumption } \\
\text { Yes } \\
\text { No }\end{array}$ & $\begin{array}{l}76(64.4) \\
2(40.0)\end{array}$ & $\begin{array}{c}42(35.6) \\
3(60.0)\end{array}$ & 0.25 \\
\hline $\begin{array}{l}\text { Current tobacco consumpti } \\
\text { Yes } \\
\text { No }\end{array}$ & $\begin{array}{c}5(45.5) \\
73(65.2)\end{array}$ & $\begin{array}{c}6(54.5) \\
39(34.8)\end{array}$ & 0.16 \\
\hline $\begin{array}{l}\text { Daily time of walk (min) } \\
<30 \\
>30\end{array}$ & $\begin{array}{l}15(71.4) \\
63(61.8)\end{array}$ & $\begin{array}{c}6(28.6) \\
39(38.2)\end{array}$ & 0.28 \\
\hline $\begin{array}{l}\text { Personal history of disease } \\
\text { Yes } \\
\text { No }\end{array}$ & $\begin{array}{l}34(63.4) \\
44(67.7)\end{array}$ & $\begin{array}{l}24(36.6) \\
21(32.3)\end{array}$ & 0.29 \\
\hline $\begin{array}{l}\text { Body mass index }\left(\mathrm{kg} / \mathrm{m}^{2}\right) \\
>30 \\
<30\end{array}$ & $\begin{array}{c}8(44.4) \\
70(66.7)\end{array}$ & $\begin{array}{l}10(55.6) \\
35(33.3)\end{array}$ & 0.06 \\
\hline $\begin{array}{l}\text { Waist circumference }(\mathrm{cm}) \\
\geq 94 \\
<94\end{array}$ & $\begin{array}{l}31(55.4) \\
47(70.1)\end{array}$ & $\begin{array}{l}25(44.6) \\
20(29.9)\end{array}$ & 0.06 \\
\hline $\begin{array}{l}\text { Neck circumference }(\mathrm{cm}) \\
\geq 37 \\
<37\end{array}$ & $\begin{array}{l}56(58.3) \\
22(81.5)\end{array}$ & $\begin{array}{c}40(41.7) \\
5(18.5)\end{array}$ & 0.02 \\
\hline
\end{tabular}

Note: Daily time of walk: the average time the subject used to walk every day; NBP: normal blood pressure; HBP: high blood pressure.

Table 3(b).

Results of the $\mathrm{X}^{2}$ test between HBP and its correlates among Assistant PE teachers in Republic of Benin ( $=123)$.

\begin{tabular}{|c|c|c|c|}
\hline Correlates of HBP & $\begin{array}{l}\text { Subjects with NBP } \\
\text { Frequencies (\%) }\end{array}$ & $\begin{array}{l}\text { Subjects with HBP } \\
\text { Frequencies (\%) }\end{array}$ & $p$ \\
\hline $\begin{array}{l}\text { Total cholesterol }(\mathrm{g} / \mathrm{L}) \\
\geq 2 \\
<2\end{array}$ & $\begin{array}{l}34(58.6) \\
39(68.4)\end{array}$ & $\begin{array}{l}24(41.4) \\
18(31.6)\end{array}$ & 0.18 \\
\hline $\begin{array}{l}\text { HDL-cholesterol }(\mathrm{g} / \mathrm{L}) \\
\leq 0,4 \\
>0,4\end{array}$ & $\begin{array}{l}27(57.4) \\
45(67.2)\end{array}$ & $\begin{array}{l}20(42.0) \\
22(32.8)\end{array}$ & 0.19 \\
\hline $\begin{array}{l}\text { LDL-cholesterol }(\mathrm{g} / \mathrm{L}) \\
\geq 0,6 \\
<0,6\end{array}$ & $\begin{array}{l}15(51.7) \\
57(67.1)\end{array}$ & $\begin{array}{l}14(48.3) \\
28(32.9)\end{array}$ & 0.10 \\
\hline $\begin{array}{l}\text { Triglycerides }(\mathrm{g} / \mathrm{L}) \\
\geq 2 \\
<2\end{array}$ & $\begin{array}{l}00 \\
72\end{array}$ & $\begin{array}{l}00 \\
42\end{array}$ & - \\
\hline $\begin{array}{l}\text { BIA } \\
\geq 2 \\
<2\end{array}$ & $\begin{array}{l}56(60.6) \\
16(76.2)\end{array}$ & $\begin{array}{c}37(39.4) \\
5(23.8)\end{array}$ & 0.13 \\
\hline $\begin{array}{l}\text { White blood cell count } \\
\geq 8 \times 10^{9} \text { cells } / \mathrm{L} \\
<8 \times 10^{9} \text { cells } / \mathrm{L}\end{array}$ & $\begin{array}{c}4(80.0) \\
68(62.4)\end{array}$ & $\begin{array}{c}1(20.0) \\
41(37.6)\end{array}$ & 0.39 \\
\hline $\begin{array}{l}\text { Neutrophil cell count } \\
\geq 5 \times 10^{9} \text { cells } / \mathrm{L} \\
<5 \times 10^{9} \text { cells } / \mathrm{L}\end{array}$ & $\begin{array}{c}4(80) \\
68(62.4)\end{array}$ & $\begin{array}{c}1(20.0) \\
41(37.6)\end{array}$ & 0.39 \\
\hline $\begin{array}{l}\mathrm{CRP}(\mathrm{mg} / \mathrm{L}) \\
\geq 6 \\
<6\end{array}$ & $\begin{array}{c}3(50.0) \\
69(63.9)\end{array}$ & $\begin{array}{c}3(50.0) \\
39(36.1)\end{array}$ & 0.38 \\
\hline
\end{tabular}

Note: CRP: C-reactive protein; BIA: biologic index of atherogenicity; NBP: normal blood pressure; HBP: high blood pressure.

is higher than that of the ones whose $\mathrm{NC}$ values are $<37 \mathrm{~cm}$ (41.7\% against $18.5 \%, p=0.02)$. An increased NC can consequently be considered correlated to HBP in this group.

\section{Results of the Logistic Regression}

When NC is introduced alone into the logistic regression, the results indicate that it contributes independently and to a significant degree, to explaining HBP occurring in the studied group, with an Odds Ratio (OR) $=3.14$ (95\% CI: $1.09-9.00 ; p$ $=0.033)$. Thus, a subject whose $\mathrm{NC}$ is $>37 \mathrm{~cm}$, is 3.14 times likely to have HBP than the one whose NC is $<37 \mathrm{~cm}$. After adjusting for age as a quantitative continuous variable, both $\mathrm{NC}$ and age contribute significantly, with respective $\mathrm{OR}=1.12$ $(95 \%$ CI: $1.02-1.23 ; p=0.012)$ for age and OR $=3.02(95 \%$ CI: $1.03-8.85 ; p=0.044)$ for NC. After adjusting for age, BMI, and $\mathrm{WC}$, age and $\mathrm{NC}$ remain in the final model of the regression (Table 4, stage 3), the two correlates which contribute to a significant degree to explaining the occurrence of HBP in the studied group, with respective $\mathrm{OR}=1.12(95 \% \mathrm{CI}: 1.02-1.23$, $p=0.012)$ and $\mathrm{OR}=3.02(95 \% \mathrm{CI}: 1.03-8.85, p=0.044)$.

Table 4.

Synthesis of the logistic regression between HBP and its correlates among Assistant PE teachers in Republic of Benin ( $=123)$.

\begin{tabular}{llcccc}
\hline Stages & $\begin{array}{c}\text { Correlate } \\
\text { variables }\end{array}$ & $\begin{array}{c}\text { Coefficients } \\
\text { of regression }\end{array}$ & $\begin{array}{c}\text { Odds } \\
\text { ratio }\end{array}$ & $\begin{array}{c}\text { Confidence } \\
\text { interval [CI] }\end{array}$ & $\boldsymbol{p}$ \\
\hline \multirow{2}{*}{$\begin{array}{l}\text { Age } \\
\text { 1 Neck circumference }\end{array}$} & 0.11 & 1.12 & $0.02-1.23$ & 0.016 \\
& $\begin{array}{l}\text { Body mass index } \\
\text { Waist circumference }\end{array}$ & 0.99 & 2.69 & $0.85-8.46$ & 0.090 \\
& 0.06 & 1.87 & $0.58-6.00$ & 0.293 \\
& Age & 0.11 & 1.12 & $0.02-1.23$ & 0.016 \\
2 & Neck circumference & 1.01 & 2.76 & $0.93-8.19$ & 0.06 \\
& Body mass index & 0.66 & 1.93 & $0.67-5.56$ & 0.218 \\
& Age & 0.12 & 1.12 & $1.02-1.23$ & 0.012 \\
& Neck circumference & 1.10 & $\mathbf{3 . 0 2}$ & $1.03-8.85$ & $\mathbf{0 . 0 4 4}$ \\
\hline
\end{tabular}

Note: $[\mathrm{CI}]$ : confidence interval [95\%]; $p$ : statistical $p$ value.

\section{Discussion}

\section{Association between HBP and Its Correlates}

Many studies showed that among the main factors associated with high blood pressure (HBP), obesity, overconsumption of salt, low consumption of potassium, psychological stress, physical inactivity, alcohol abuse, etc. are triggers, particularly in black African peoples (Opie \& Yackoob, 2005; WGPPH, 1993; Elliot, 1991). Our results confirm the obvious relations between HBP and a type of obesity (upper body) but not those with factors related to lifestyle or category of age. Thus, the cut off value used (i.e. 50 years) for transforming age into qualitative variable does not appear reliable, since introducing age into the logistic regression as a continuous variable, shows that it contributes significantly to the occurrence of HBP. If obesity constitutes a factor associated with HBP, the seniority in the profession seems to potentiate this relation (Soteriados et al., 2005; Rotimi et al., 1995), but it is not the case in our series. It is known that the environmental factors which a cohort is subjected to at a given moment, influence in a substantial way the distribution and the degree of obesity in this cohort (O'Donovan et al., 2005). Since the majority of the PE teachers of this study usually move in car or on motorcycle and no longer have regular physical activities, it is reasonable to think that the prevalence of HBP and obesity recorded are strongly associated to their inactivity. They would thus have involved in sedentary practices, coupled with high consumption of saturated fat and salt, reducing the positive effects of their working conditions 
(Misigoj-Durakovic et al., 2004). Since the individuals who exercise have a better physical fitness than the non-active and a more favorable cardiovascular risk profile (Francischetti \& Genelhu, 2007), it is suggestible that the overweight and obese subjects of our sample resume exercises, while reducing saturated fat, salt, tobacco and alcohol consumption. HBP indeed has a specific pathogenic support in blacks, since: 1) endothelin has been found at higher concentration in black subjects with arterial hypertension; 2) the genome contributes in this pathogenesis, by the means of the genes M-235T coding angiotensinogen and that located on the chromosome $10 \mathrm{p}$, which is implied in the end-stage renal failure; 3 ) this pathogenesis is especially related to the increased sensitivity of black peoples to sodium load, a defect of urinary sodium excretion and a low plasma renin activity (Aubry, 2003).

In a study carried out in Estonia, Pihl et al., (2002) noted that $59.3 \%$ of the PE teachers do exercise regularly during their leisure time and that the risk of obesity $(\mathrm{OR}=0.63 ; 95 \% \mathrm{CI}$ : $0.21-0.94)$ and hypertension $(\mathrm{OR}=0.52 ; 95 \% \mathrm{CI}: 0.29-0.94)$ was lower than that of the non-teachers enrolled as controls. Sandmark (2000) also reported that when they were 25 years old, the Swedish PE teachers had on average a BMI higher than that of the non-teachers, but at a more advanced age, the BMI of the teachers were on average lower. According to the author, this report is related to the fact that the subjects who pursue sporting practice are more numerous in the group of teachers. In Croatia, the PE teachers have on average a level of sporting practice or leisure physical activity higher than that of the other employees of the country. That had a positive impact on the prevalence of cardiovascular risk factors like overweight, obesity, systolic high pressure and high level of plasma cholesterol (Misigoj-Durakovic et al., 2004). More recently, Mbemba et al. (2007) observed in Congo a prevalence of $21 \%$ of stage I of hypertension in PE teachers with a reduced physical activity, against $1.56 \%$ in the group of subjects with a high level of physical activity. Our results tend to corroborate this previous finding.

The lifestyle change recommended by Francischetti and Genelhu (2007) can also offer other benefits to the PE teachers of this study: 1) it can enable them to become aware and to better counsel the youngsters for the adoption of favourable behaviour towards cardiovascular health (O'Loughlin et al., 1996); 2) while becoming more physically active, the PE teachers will be more fit and, as it was shown in Israeli PE female teachers, their behaviour in ageing periods could become more positive (Netz \& Raviv, 2002).

In our cohort, the WBC and neutrophil (NEU) counts do not appear associated with arterial hypertension. Studies like that of Horne et al. (2005) however, highlighted the strong relation between increased WBC count, NEU, NEU/WBC ratio and an increased risk of cardiovascular disease. Recently, Orakzai et al. (2006) noted in white men that the WBC count is associated with high SBP values of about $130-139 \mathrm{~mm} \mathrm{Hg}(\mathrm{OR}=1.5$; $95 \%$ CI: $1.15-1.92, p<0.05)$. This aspect of our results must be deepened and on this assumption, the relations between the emergent risk factors (homocystein, fibrinogen, (Lpa) lipoprotein, CRP, WBC and NEU counts) and arterial hypertension may be evaluated in the various parts of the population in subSaharan Africa.

\section{Multivariate Analysis}

In this study, neck circumference (NC) is the only modifiable variable associated with HBP for $p<0.05$, and a subject whose $\mathrm{NC}$ is high, is 3.02 times more likely to have HBP than another one whose $\mathrm{NC}$ is below the borderline value. Ben-Noun et al. (2001) showed that NC constitutes the most reliable index of body fat mass distribution in the upper body. Ben Noun and Laor (2003) even showed that a high value of NC can increase the risk of coronary disease. Considering his finding, this study seems to corroborate with regard to HBP. If however one raises the level of significance of the $X^{2}$ test up to $p<0.10$, the percentages of the two groups of teachers with HBP also present significant differences for BMI $(p=0.06)$ and WC $(p=0.06)$ subgroups. That means we could think that for a higher $\mathrm{p}$ value, these two adiposity indexes of which one (BMI) accounts for the total adiposity of the body and the other (WC), accounts for obesity in the upper body, are also associated to HBP. However, it does not seem to be the case among our PE teachers, since in the logistic model, these two adiposity indexes do not contribute to a significant degree to explain HBP occurring.

In this context, the type of HBP recorded in the current study can be compared to that reported recently under the name of hypertension associated with obesity, by Francischetti and Genelhu (2007). It would be the leptin, a protein secreted by and in the adipocytes, which binds obesity to HBP/hypertension and an increase in the sympathetic activity of the nervous system. The potential mechanisms involved in this hypertension associated with obesity are: hypoadiponectinemy, a high concentration of circulating free fatty acids and an increased production of endothelin-1 (ET-1) (Francischetti \& Genelhu, 2007) which we could not unfortunately assess. It is the same case for glycaemia, blood potassium and salt intake that we could not assess in the conditions the study was carried out. Problems of participants and material availability were so critical issues that we decided to collect data although study limits attached to this choice. Once more, this study raised the reality of research carrying out in Developing Countries, in particular those of sub-Saharan Africa in which sociocultural factors often add to material unavailability to weaken research designs initiated by natives.

\section{Conclusion}

The results of this study revealed that the APE teachers studied have a lifestyle favourable to weight gain and increased blood pressure. The frequencies of high blood pressure and its correlates related to upper body obesity are high among them. The multivariate analysis showed that in this particular sample of APE teachers, neck circumference, a reliable indicator of upper body obesity, may be considered as one of the most relevant variable explaining high values of blood pressure.

These results suggest that the APE teachers and all the PE teachers in general, must keep on exercising as early as their initial training comes to an end. They also have to avoid overconsumption of salt, alcoholic drinks and saturated lipids. Doing so, they could avoid overweight and reduce the risk of hypertension. We agree with Gaziano et al. (2005) that the use of quantitative risk based guidelines for treatment of hypertension could free up major resources for other pressing needs, especially in developing countries. However, it can be suggested that for the moment, a periodic measurement of blood pressure for early detection and care for the PE teachers at risk of HBP may be integrated into the national programmes of non-transmissible disease prevention. 


\section{Acknowledgements}

The authors are grateful to Mr. Chogninka Roland, which accepted to undertake blood tests in his Laboratory, and conceded a substantial financial reduction on the real fees. We thank all the APE teachers who took part in this study, for their availability. We are also indebted to the managers of the Centre of Muscular and Cardiovascular Maintenance VITAFORME of Porto-Novo, for their technical support during data processing and analysis.

\section{REFERENCES}

Agboton, H., Massougbodji, M., Badarou, G., Akindes, R., Dossouvi, C., \& Hazoume, F. (1987). Le profil tensionnel de l'enfant béninois. Santé Publique Bénin, 1, 667-670.

Akplogan, L., Agboton, H., \& Corneau, B. (1985). Résultats préliminaires de l'évaluation du risque athérogène des lipides chez les Béninois. Le Bénin Médical, 1, 1-5.

Aubry, P. (2003). L'évolution des maladies cardiovasculaires dans les pays en développement. Médecine Tropicale, 20, 1-2.

Ben Noun, L., \& Laor, A. (2003). Relationship of neck circumference to cardiovascular risk factors. Obesity Research, 11, 226-231. doi:10.1038/oby.2003.35

Ben-Noun, L., Sohar, E., \& Laor, A. (2001). Neck circumference as a simple screening measure for identifying overweight and obese patients. Obesity Research, 9, 470-477. doi:10.1038/oby.2001.61

Boreham, C., Savage, J. M., Primrose, D., Cran, G., \& Strain, J. (1993). Coronary risk factors in schoolchildren. Archives of Disease in Childhood, 68, 182-186. doi:10.1136/adc.68.2.182

Daniels, S. R., Kimball, T. R., Khour, Y. P., Witt, S., \& Morrison, J. A. (1996). Correlates of the hemodynamic determinants of blood pressure. Hypertension, 28, 37-41.

Elliot, P. (1991). Observational studies on salt and blood pressure. Hypertension, 17, 13-18.

Fourcade, L., Paule, P., \& Mafart, B. (2007). Arterial hypertension in sub-Saharan Africa. Update and perspectives. Medecine Tropicale, 67, 559-567.

Francischetti, E. A., \& Genelhu, V. (2007). A Obesity-hypertension: An ongoing pandemic. International Journal of Clinical Practice, 61, 269-280. doi:10.1111/j.1742-1241.2006.01262.x

Gaziano, T. A., Steyn, K. N., Cohen, D. J., Weinstein, M. C., \& Opie, L. H. (2005). Cost-Effectiveness analysis of hypertension guidelines in South Africa: Absolute risk versus blood pressure level. Circulation, 112, 3569-3576. doi:10.1161/CIRCULATIONAHA.105.535922

Guenette, A. A., \& Mantha, M. M. (2005). Hypertension. Fiche santé du réseau proteus. Révision médicale par Lépine, $\mathrm{P}$. (Dernière mise à jour, le 10 Octobre 2005, consultée le 21 Janvier 2008).

http://www.passeportsanté.net

Hagberg, J. M., Goldring, D., Eshani, A. A., Heath, G. W., Hernandez, A., \& Schechtman, K. et al. (1983). Effect of exercise training on blood pressure and hemodynamic features of hypertensive adolescents. American Journal of Cardiology, 52, 763-768. doi:10.1016/0002-9149(83)90412-5

Horne, B. D., Anderson, J. L., John, J. M., Weaver, A., Bair, T. L., \& Jensen, K. R. (2005). Which white blood cell subtypes predict increased cardiovascular risk? Journal of American College of Cardiology, 45, 1638-1643. doi:10.1016/i.jacc.2005.02.054

Jeppesen, J., Ole Hein, H., Suadicani, P., \& Gyntelberg, F. (2003). High triglycerides/low high-density lipoprotein cholesterol, ischemic electrocardiogram changes, and risk of ischemic heart disease. American Heart Journal, 145, 103-108. doi:10.1067/mhj.2003.45

Mac Dougall, J. D., Howard, A. W., \& Howard, J. G. (1988). Evaluation physiologique de l'athlète de haut niveau. Paris: Décarie Vigot.

Mbemba, F. I., Bazolo, P., Ouissika, G. S., Bazaba, A., \& Senga, P. (2007). Hypertension artérielle: Absence d'activité physique ou origine nutritionnelle? Médecine d'Afrique Noire, 54, 383-387.

Misigoj-Durakovic, M., Durakovic, Z., Ruzic, L., \& Findak, V. (2004).
Gender differences in cardiovascular diseases risk for physical education teachers. Collegium Antropologicum, 28, 251-257.

Mujika, I., \& Padilla, S. (2000). Detraining: Loss of training-induced physiological and performance adaptations. Part II: Long term insufficient training stimulus. Sports Medicine, 30, 145-154. doi:10.2165/00007256-200030030-00001

Mujika, I., \& Padilla, S. (2001). Cardiorespiratory and metabolic characteristics of detraining in humans. Medicine and Science in Sports and Exercise, 33, 413-421. doi:10.1097/00005768-200103000-00013

Nelson, L., Esler, M. D., \& Jennings, G. L. (1986). Effects of changing levels of physical activity on blood pressure and haemodynamics in essential hypertension. Lancet, 2, 473-476. doi:10.1016/S0140-6736(86)90354-5

Netz, Y., \& Raviv S. (2002). Exercise, fitness, and subjective measures related to fitness of physical education and other teachers. Perceptual and Motor Skills, 94, 1091-1100.

O’Donovan, G., Owen, A., Kearney, E. M., Jones, D. W., Nevill, A. M., Woolf-May, K. et al. (2005). Cardiovascular disease risk factors in habitual exercisers, lean sedentary men and abdominally obese sedentary men. International Journal of Obesity, 29, 1063-1069. doi:10.1038/sj.ijo.0803004

O’Loughlin, J., Renaud, L., Paradis, G., \& Meshefedjian, G. (1996). Screening school personnel for cardiovascular disease risk factors: Short-term impact on behavior and perceived role as promoters of heart health. Preventive Medicine, 25, 660-667. doi:10.1006/pmed.1996.0104

Opie, L. H., \& Yackoob, K. S. (2005). Hypertension in sub-Saharan African populations. Circulation, 112, 3562-3568. doi:10.1161/CIRCULATIONAHA.105.539569

Orakzai, R. H., Orakzai, S. H., Nasir, K., Santos, R. D., Rana, J. S., Pimentel, I. et al. (2006). Association of white blood cell count with systolic blood pressure within the normotensive range. Journal of Human Hypertension, 20, 310-312. doi:10.1038/sj.jhh.1001992

World Health Organization (1999). International society of hypertension. Guidelines subcommittee. Guidelines for the management of hypertension. Journal of Hypertension, 17, 151-183.

Ortlepp, J. R., Metrikat, J., Albrecht, M., Maya-Pelzer, P., Pongratz, H. \& Hoffmann, R. (2003). Relation of body mass index, physical fitness, and the cardiovascular risk profile in 3127 young normal weight men with an apparently optimal lifestyle. International Journal of Obesity and Related Metabolic Disease, 27, 979-982. doi:10.1038/sj.ijo.0802319

Oshida, Y., Yamanouchi, K., Hayamizu, S., Nagasawa, J., Ohsawa, I., \& Sato, Y. (1991). Effects of training and training cessation on insulin action. International Journal of Sports Medicine, 12, 484-486. doi: $10.1055 / \mathrm{s}-2007-1024718$

Petibois, C., \& Deleris, G. (2003). Effects of short and long term detraining on metabolic response to exercise. International Journal of Sports Medicine, 24, 320-325. doi:10.1055/s-2003-40708

Petibois, C., Cassaigne, A., Gin, H., \& Deleris, G. (2004). Lipid profile disorders induced by long-term cessation of physical activity in previously highly endurance-trained subjects. Journal of Clinical Endocrinology and Metabolism, 89, 3377-3384. doi: $10.1210 /$ jc. 2003-031311

Pihl, E., Matsin, T., \& Jürimäe, T. (2002). Physical activity, musculoskeletal disorders and cardiovascular risk factors in male physical education teachers. Journal of Sports Medicine and Physical Fitness, 42, 466-471

Pouliot, M. C., Despres, J. P., Lemieux, S., Moorjani, S., Bouchard, C., Tremblay, A. et al. (1994). Waist circumference and abdominal sagittal diameter: Best simple anthropometric indexes of abdominal visceral adipose tissue accumulation and related cardiovascular risk in men and women. American Journal of Cardiology, 73, 460-468. doi:10.1016/0002-9149(94)90676-9

Rotimi, C. N., Cooper, R. S., Ataman, S. L., Osotimehin, B., Kadiri, S., Muna, W. et al. (1995). Distribution of anthropometric variables and the prevalence of obesity in populations of West African origin: The International Collaborative Study on Hypertension in Blacks (ICSHIB). Obesity Research, 3, 95-105.

Sandmark, H. (2000). Musculoskeletal dysfunction in physical education teachers. Occupational and Environmental Medicine, 57, 673- 


\section{P. GOUTHON ET AL.}

677. doi: $10.1136 / \mathrm{oem} .57 .10 .673$

Soteriades, E. S., Hauser, R., Kawachi, I., Liarokapis, D., Christiani, D. C., \& Kales, S. N. (2005). Obesity and cardiovascular disease risk factors in fire-fighters: A prospective cohort study. Obesity Research, 13, 1756-1763. doi:10.1038/oby.2005.214
Working Group on Primary Prevention of Hypertension (WGPPH) (1993). Report of the National High Blood Pressure Education Program. Archives of Internal Medicine, 153, 186-208.

doi:10.1001/archinte.1993.00410020042003 